\title{
Role of REG I $\alpha$ in gastric carcinogenesis: Gastrin-associated proliferative and anti-apoptotic activities
}

\author{
QUNYAN ZHOU ${ }^{2}$, XIAOFENG LU ${ }^{2}$, LIHONG GAN $^{1}$, SHUJIE CHEN ${ }^{2}$, \\ TIANHUA ZHOU ${ }^{3}$, LIANGJING WANG ${ }^{1}$ and JIANMIN $\mathrm{SI}^{2}$ \\ ${ }^{1}$ Department of Gastroenterology, Second Affiliated Hospital, Zhejiang University, School of Medicine, \\ Hangzhou 310009; ${ }^{2}$ Laboratory of Digestive Disease, Clinical Institution of Sir Run Run Shaw Hospital, \\ Zhejiang University, Hangzhou 310016; ${ }^{3}$ Department of Cell Biology and Program in Molecular Cell Biology, \\ Zhejiang University, School of Medicine, Hangzhou 310058, P.R. China
}

Received June 18, 2010; Accepted September 7, 2010

DOI: $10.3892 / \mathrm{mmr} .2010 .364$

\begin{abstract}
Gastric carcinogenesis is a multiple-stage process. It is believed that a premalignant lesion often precedes or accompanies gastric cancer, although the underlying mechanisms have not been fully elucidated. Here, we revealed that REG I $\alpha$ was frequently overexpressed not only in gastric cancer tissues, but also in the intestinal metaplastic and atypical dysplasia gland, which are considered precancerous lesions, in 102 patients. To investigate the role of REG I $\alpha$ in gastric cancer, we employed siRNA-mediated silencing techniques and found that the downregulation of REG I $\alpha$ significantly inhibited gastric cancer cell proliferation, whereas overexpression of REG I $\alpha$ promoted proliferation. In addition, REG I $\alpha$ appeared to have an anti-apoptotic effect in gastric cancer cells, which was associated with the Bad/ Bcl-xL/caspase-3 pathway. Furthermore, gastrin was found to activate REG I $\alpha$ expression and nuclear translocation of $\beta$-catenin in gastric cancer cells. Thus, these data suggest that REG I $\alpha$, a potential downstream of gastrin, may be involved in gastric carcinogenesis.
\end{abstract}

\section{Introduction}

Despite significant advances in basic and clinical research on gastric cancer, it remains the second leading cause of cancer-related death in the world $(1,2)$. According to Correa's hypothesis, the development of gastric cancer is a multiple-

Correspondence to: Professor Liangjing Wang, Department of Gastroenterology, Second Affiliated Hospital, Zhejiang University, School of Medicine, Hangzhou 310009, P.R. China

E-mail:wanglj76@hotmail.com

Professor Jian-min Si, Laboratory of Digestive Disease, Clinical Institution of Sir Run Run Shaw Hospital, Zhejiang University, Hangzhou 310016, P.R. China

E-mail: sijm@zju.edu.cn

Key words: regeneration gene I $\alpha$, gastric cancer, gastrin, $\beta$-catenin stage process. Atrophic gastritis, intestinal metaplasia (IM) and dysplasia are considered precancerous lesions associated with a considerable risk of developing into gastric carcinoma (3). It is believed that gastric premalignant lesions often precede or accompany gastric cancer, although the underlying mechanisms have not been fully elucidated (4).

A pathogenic link to gastric cancer may be related to growth factors and inflammatory mediators of Helicobactor pylori (H. pylori) infection in gastric glands (5). Indeed, studies have shown that growth factors, including epidermal growth factor (EGF), transforming growth factor- $\alpha$ (TGF- $\alpha$ ) and vascular endothelial growth factor (VEGF), appear to be responsible for epithelial cell regeneration and gland restoration in gastritis; furthermore, overexpression of these growth factors promotes proliferation, differentiation, invasion and metastasis of gastric cancer cells $(6,7)$. Thus, growth factors may play an important role in the progression from chronic gastritis to gastric cancer. Although growth factors are predicted to play a key role in the progression from chronic gastritis to gastric cancer, the underlying molecular mechanisms involved in this transition are poorly understood.

The regenerating gene (REG) I $\alpha$ was first isolated as a trophic or growth factor in regenerating pancreatic islet cells (8). REG I $\alpha$ protein is a member of the REG family that is predominantly expressed in the normal pancreas and at low levels in the stomach and colon, suggesting physiological roles for REG I $\alpha$ in these organs (9). Previous studies have reported that REG I $\alpha$ was overexpressed in $H$. pylori-induced gastritis and gastric ulcer lesions (10-12). Notably, studies have also shown that REG I $\alpha$ promoted gastric cell growth and differentiation in the neck zone, suggesting a role as a potent trophic agent of progenitor cells of the gastric fundic mucosa $(13,14)$. In addition to the important role of REG I $\alpha$ in the pathogenesis of gastric inflammatory diseases, REG I $\alpha$ has been proposed to function in the carcinogenesis of gastrointestinal tissues, including the pancreas (15), colon (16) and liver (17). However, the role of REG I $\alpha$ in gastric precancerous lesions and in the development of gastric cancer remains poorly understood.

REG I $\alpha$ is produced primarily by enterochromaffin-like (ECL) cells and chief cells in human gastric mucosa. Gastrin 
Table I. Primers used for PCR amplification of REG I $\alpha$.

\begin{tabular}{llc}
\hline Gene & \multicolumn{1}{c}{ Primer sequence } & Product size (bp) \\
\hline REG I $\alpha$ (RT-PCR) & Forward: 5'-GATTGTTGATTTGCCTCTTA-3' & 557 \\
NM_002909.4 & Reverse: 5'-TCCAGCTGCCTCTAGTTTTTGAA-3' & 306 \\
REG I $\alpha($ Q-PCR) & Forward: 5'-TGCCTATCGCTCCTACTGCT-3' & \\
NM_002909.4 & Reverse: 5'-CTTGAGGTCAGGCTCACACA-3' & 226 \\
GAPDH & Forward: 5'-GAAGGTGAAGGTCGGAGT-3' \\
NM_002024.3 & Reverse: 5'-GAAGATGGTGATGG'GATTTC-3' & \\
\hline
\end{tabular}

was previously shown to stimulate REG I $\alpha$ production by ECL cells (18-20). As gastrin does not directly promote proliferation of cultured rat gastric epithelial cells, it was proposed that REG I $\alpha$ indirectly regulates proliferation via gastrin; however, the gastrin-associated pathway involved in REG I $\alpha$ stimulation remains unclear. Previous studies found that REG I $\alpha$ was overexpressed in human primary liver tumors and that REG I $\alpha$ may act as a downstream target of the $\beta$-catenin pathway during liver tumorigenesis (21).

In the present study, we provide evidence that REG I $\alpha$ expression is involved in the progression from active gastritis and precancerous lesions to gastric cancer. We report that REG I $\alpha$ promotes cell proliferation and appears to have an anti-apoptotic effect via the $\mathrm{Bad} / \mathrm{Bcl}-\mathrm{xL} /$ caspase-3 pathway in gastric cancer cells. Finally, gastrin activated REG I $\alpha$ expression and induced $\beta$-catenin nuclear translocation in gastric cancer cells.

\section{Materials and methods}

Clinical samples. Gastric biopsy specimens were obtained from the Endoscopy Centre of Sir Run Run Show Hospital and the Second Affiliated Hospital, Zhejiang University, School of Medicine. A total number of 102 patients were enrolled in the study, and gastric biopsy tissue samples were grouped as follows: normal gastric tissue without $H$. pylori infection (control, $\mathrm{n}=25$ ); active gastritis with $H$. pylori infection (AG, $\mathrm{n}=20$ ); intestinal metaplasia (IM, $\mathrm{n}=40$ ); and dysplasia (DYS, $\mathrm{n}=17$ ). Thirty surgically resected gastric cancer (GC, $\mathrm{n}=30$ ) specimens were also obtained from Sir Run Run Shaw Hospital. Gastric carcinoma was classified according to the WHO criteria and staged according to the tumornode-metastasis (TNM) system. The IM and DYS samples were evaluated according to the updated Sydney system. All specimens were immediately snap-frozen in liquid nitrogen and stored at $-80^{\circ} \mathrm{C}$ until further processing. Total RNA was extracted using Trizol reagent.

Cell culture. Human gastric cancer cell lines, AGS, NCI-N87, BCG-823 and SGC-7901, were purchased from the American Type Culture Collection (ATCC, Manassas, VA, USA). Human gastric cancer cell lines, MKN28 and MKN45, were gifts from the laboratory of Professor Wang Linbo (Oncology Department, Sir Run Run Shaw Hospital). Unless specifically indicated, cells were cultured in RPMI-1640 medium (Invitrogen, USA) supplemented with penicillin and strepto- mycin and $10 \%$ fetal bovine serum, and the cells were grown in a $37^{\circ} \mathrm{C}$ incubator with $5 \% \mathrm{CO}_{2}$ and $95 \%$ humidity.

Plasmid construction, transfections and stable clone establishment. The full-length human REG I $\alpha$ cDNA was inserted into the pIRES2-EGFP vector to generate the pIRES2-REGI $\alpha$ expression vector, and the pIRES2-EGFP vector was used as the negative control. REG I $\alpha$-directed siRNA duplex oligoribonucleotides and control siRNAs were both designed and purchased from Genscript (Nanjing, China). The REG I $\alpha$ target site was CTCAAGCACAGGATTCCAGAAA. The REG I $\alpha$ siRNA was inserted into the pRNAT-CMV3.1 expression vector. To establish stable clones, MKN28 and MKN45 gastric cancer cells were cultured for $24 \mathrm{~h}$ in 12 -well plates $\left(1.0 \times 10^{5}\right.$ cells/well). The pIRES2-REG I $\alpha$ or REG I $\alpha$ iRNA vector $(1.6 \mu \mathrm{g}$ plasmid for each well) was transfected with Lipofectamine 2000 (4.0 $\mu \mathrm{l} /$ well) (Invitrogen), and the pIRES2-EGFP or control siRNA was transfected as negative controls, respectively. After $18 \mathrm{~h}$, the transfectants were replated and selected by growth in medium containing G418 (500 $\mu \mathrm{g} / \mathrm{ml})$ (Merck, Germany) for 8 weeks to obtain positive monoclonal cells.

Reverse transcription PCR and quantitative real-time PCR. REG I $\alpha$ mRNA expression in gastric cancer cell lines was detected by reverse transcription polymerase chain reaction (RT-PCR) and real-time quantitative reverse transcription PCR (Q-PCR), and REG I $\alpha$ mRNA from the gastric specimens was detected by Q-PCR. Total RNA $(1 \mu \mathrm{g})$ was reverse transcribed into cDNA using Oligo (dT) 15 primers and Takara reverse transcriptase (Takara, China). RT-PCR was performed under conditions of 25 cycles of denaturation $\left(30 \mathrm{sec}\right.$ at $95^{\circ} \mathrm{C}$ ), annealing $\left(30 \mathrm{sec}\right.$ at $\left.54^{\circ} \mathrm{C}\right)$ and extension $\left(30 \mathrm{sec}\right.$ at $72^{\circ} \mathrm{C}$ ). Q-PCR was performed using the SYBR Green Master Mix kit (Takara) in the ABI 7500 machine (ABI, USA). Human GAPDH was used as an endogenous control, and the expression levels of REG I $\alpha$ mRNA were determined using the $2^{-\Delta \Delta C t}$ method. All primers are listed in Table I.

Cell proliferation assay. Cells growth was determined in proliferation assays based on the reagent 3-(4,5-methylthiazol2-yl)-2, 5-diphenyltetrazolium bromide (MTT). Briefly, stable transfected cells were grown into 96-well plates, and $20 \mu \mathrm{l}$ of MTT $(5 \mathrm{mg} / \mathrm{ml})$ was added at $0,24,48,72$ and $96 \mathrm{~h}$. The medium was discarded after $4 \mathrm{~h}$. Formazan products were solubilized with dimethyl sulphoxide (DMSO), and the optical density (OD) was measured at $570 \mathrm{~nm}$. 
Cell apoptosis analysis. Percentages of cell apoptosis were determined by flow cytometry using the Annexin V-FITC Apoptosis Detection kit (Invitrogen). Cells were gently harvested and plated in 6-well dishes $\left(5 \times 10^{5}\right.$ cells/well). The cells were then suspended in $100 \mu 1 \mathrm{lX}$ binding buffer, $5 \mu 1$ Alexa Fluor 488 annexin $\mathrm{V}$ and $1 \mu \mathrm{l}$ propidium iodide (PI, $100 \mu \mathrm{g} / \mathrm{ml}$ ). After a 15-min incubation, the cells were mixed with binding buffer on ice, and the apoptotic distribution of the stained cells was analyzed by flow cytometry (BD, USA).

Gastrin 17 (G17) and $\mathrm{H}_{2} \mathrm{O}_{2}$ treatment of cells. AGS cells cultured in 96-well plates $\left(2 \times 10^{3}\right.$ cells/well) were starved for $24 \mathrm{~h}$ and grown in medium containing gastrin-17 (G17) (Sigma, USA) at concentrations of $0,10^{-8}, 10^{-7}$ and $10^{-6} \mathrm{~mol} / 1$ for $0,24,48,72$ and $96 \mathrm{~h}$. MKN28 cells stably transfected with the pIRES2-REG I $\alpha$ or the pIRES2-EGFP vector were seeded in 96-well plates $\left(2 \times 10^{4}\right.$ cells/well) and incubated with $\mathrm{H}_{2} \mathrm{O}_{2}$ (0, 100, 200 and $800 \mu \mathrm{mol} / \mathrm{l})$ for $6 \mathrm{~h}$. The $\mathrm{H}_{2} \mathrm{O}_{2}$-containing medium was replaced with fresh medium, and cell activities were evaluated at $0,24,48$ and $72 \mathrm{~h}$.

Immunoblotting. Cells were harvested, and whole cell lysates were prepared by extraction with radio immunoprecipitation assay (RIPA) lysis buffer containing protease inhibitors. Cytoplasmic and nuclear protein fractions were extracted using a nuclear and cytoplasmic protein extraction kit (Beyotime, China). Total protein $(40 \mu \mathrm{g})$ was loaded in each well, and the proteins were separated by $12 \%$ SDS-PAGE and blotted onto polyvinylidene difluoride (PVDF) membranes. The membranes were incubated with mouse monoclonal anti-caspase-3/Bcl-xL antibody (1:500) (Sigma), mouse monoclonal anti-Bad antibody $(1: 1,000)$ (Abnova, Taiwan), or rabbit polyclonal anti-human $\beta$-catenin $(1: 1,000)$ (Cell Signal, USA) overnight at $4^{\circ} \mathrm{C}$. Horseradish peroxidase-conjugated goat anti-rabbit or anti-mouse $\operatorname{IgG}(1: 2,500)$ (MultiSciences Biotech, China) was used for enhanced chemiluminescence detection with an LAS-4000 image system. $\beta$-actin $(1: 10,000)$ (Sigma) and lamin B (1:500) (Abcam) antibodies were used to normalize the protein levels.

Statistical analysis. All data were analyzed using SPSS 13.0 statistical software. Continuous variables are expressed as the mean \pm SEM. Multi-group data were assessed by the analysis of variance (ANOVA). When comparing the means between two groups, we used LSD for homogeneity of variance and Dunnett's $\mathrm{C}$ test for heterogeneity of variance. T-tests were used to compare two groups of continuous variables. Fisher's exact test was used for categorical variables. A P-value $<0.05$ was considered to indicate statistical significance.

\section{Results}

REG I $\alpha$ overexpression is associated with gastric carcinogenesis and poor differentiation in gastric cancer. We examined REG I $\alpha$ mRNA expression levels in 102 gastric biopsy specimens and 30 surgically resected gastric cancer tissue samples by Q-PCR. Gastric biopsy specimens were categorized into the following groups: normal gastric tissue without $H$. pylori infection $(\mathrm{n}=25)$, active gastritis with $H$. pylori infection (AG, $\mathrm{n}=20$ ), intestinal metaplasia (IM, $\mathrm{n}=40$ ) and dysplasia (DYS, $\mathrm{n}=17)$. REG I $\alpha$ expression was significantly upregulated in GC tissues and precancerous lesions (DYS and IM) relative to the normal $H$. pylori-negative gastric tissues $(\mathrm{P}<0.05)$. However, there was no statistical significant difference between the mRNA expression of REG I $\alpha$ between the AG, IM and DYS samples. We determined that REG I $\alpha$ was highly expressed under these clinical conditions (Fig. 1A).

We further evaluated the relationship between the pathological status of GC and REG I $\alpha$ mRNA expression levels when matched with general patient characteristics, including age and gender $(\mathrm{P}>0.05)$ (Table II). The results showed that REG I $\alpha$ mRNA was highly expressed in late-stage GC specimens (stage III, stage IV) relative to early-stage specimens (stage I/II) $(\mathrm{P}<0.01)$ (Fig. 1B). We also examined REG I $\alpha$ mRNA expression levels in human differentiated gastric cancer cell lines (AGS, MKN28, MKN45, NCI-N87, BCG-823 and SGC-7901) using RT-PCR and Q-PCR. We found that REG I $\alpha$ mRNA expression was higher in the less-differentiated AGS and MKN45 gastric cancer cell lines (Fig. 1C). Collectively, the results of these experiments showed that REG I $\alpha$ overexpression was associated with gastric precancerous lesions and gastric cancer, and may predict poorly differentiated gastric cancer.

REG I $\alpha$ overexpression enhances, whereas REG I $\alpha$ downregulation inhibits, gastric cancer cell growth. To determine whether REG I $\alpha$ regulates cell proliferation, we stably transfected MKN28 cells, which express low levels of endogenous REG I $\alpha$, with the pIRES2-REG I $\alpha$ plasmid to overexpress REG I $\alpha$. We also stably transfected MKN45 cells, which express high levels of endogenous REG I $\alpha$, with the pCMV3.1REGI $\alpha$ siRNA vector to inhibit REG I $\alpha$ expression. REG I $\alpha$ expression levels were determined in individual clones by RT-PCR analysis (Fig. 2A). The results of MTT assays showed that cell proliferation was significantly higher in the MKN28 cells overexpressing REG I $\alpha$ relative to the negative controls at 24 and $48 \mathrm{~h}(\mathrm{P}<0.01)$ (Fig. 2B). In contrast, cell proliferation was significantly lower in the MKN45 cells with decreased REG I $\alpha$ expression at 24,48 and $72 \mathrm{~h}$ relative to the negative controls $(\mathrm{P}<0.01)$ (Fig. 2C). Taken together, the results of these experiments suggest that REG I $\alpha$ positively regulates gastric cancer cell growth and proliferation.

REG Ia mediates an anti-apoptotic effect in gastric cancer cells via the Bad/Bcl-xL/caspase-3 pathway. We also carried out experiments to determine whether REG I $\alpha$ has an anti-apoptotic effect in gastric cancer cells. We found a significantly higher number of early apoptotic cells in REG I $\alpha$ siRNA-transfected MKN45 cells relative to the control cells $(12.96 \pm 0.5$ vs. $3.99 \pm 0.3 \%$, respectively; $\mathrm{P}<0.001)$ (Fig. 3A). To induce cell apoptosis, MKN28 cells overexpressing REG $\mathrm{I} \alpha$ were treated with increasing concentrations of $\mathrm{H}_{2} \mathrm{O}_{2}$ for 6 h. Flow cytometry showed that MKN28 cells overexpressing REG I $\alpha$ exhibited lower apoptosis relative to the negative controls when exposed to $\mathrm{H}_{2} \mathrm{O}_{2}(200 \mu \mathrm{mol} / \mathrm{l})$ for $6 \mathrm{~h}$ $(21.32 \pm 1.25$ vs. $27.14 \pm 0.82 \%$, respectively; $\mathrm{P}<0.05)$ (Fig. $3 \mathrm{~B}$ ). The results of the MTT assays showed that cell growth was higher in MKN28 cells overexpressing REG I $\alpha$ relative to the negative controls following treatment with $\mathrm{H}_{2} \mathrm{O}_{2}(200 \mu \mathrm{mol} / \mathrm{l})$ for $6 \mathrm{~h}$ (OD value: $1.73 \pm 0.067$ vs $1.44 \pm 0.131, \mathrm{P}<0.01$ ) (Fig. $3 \mathrm{C}$ ). We also carried out experiments to determine whether REG I $\alpha$ 


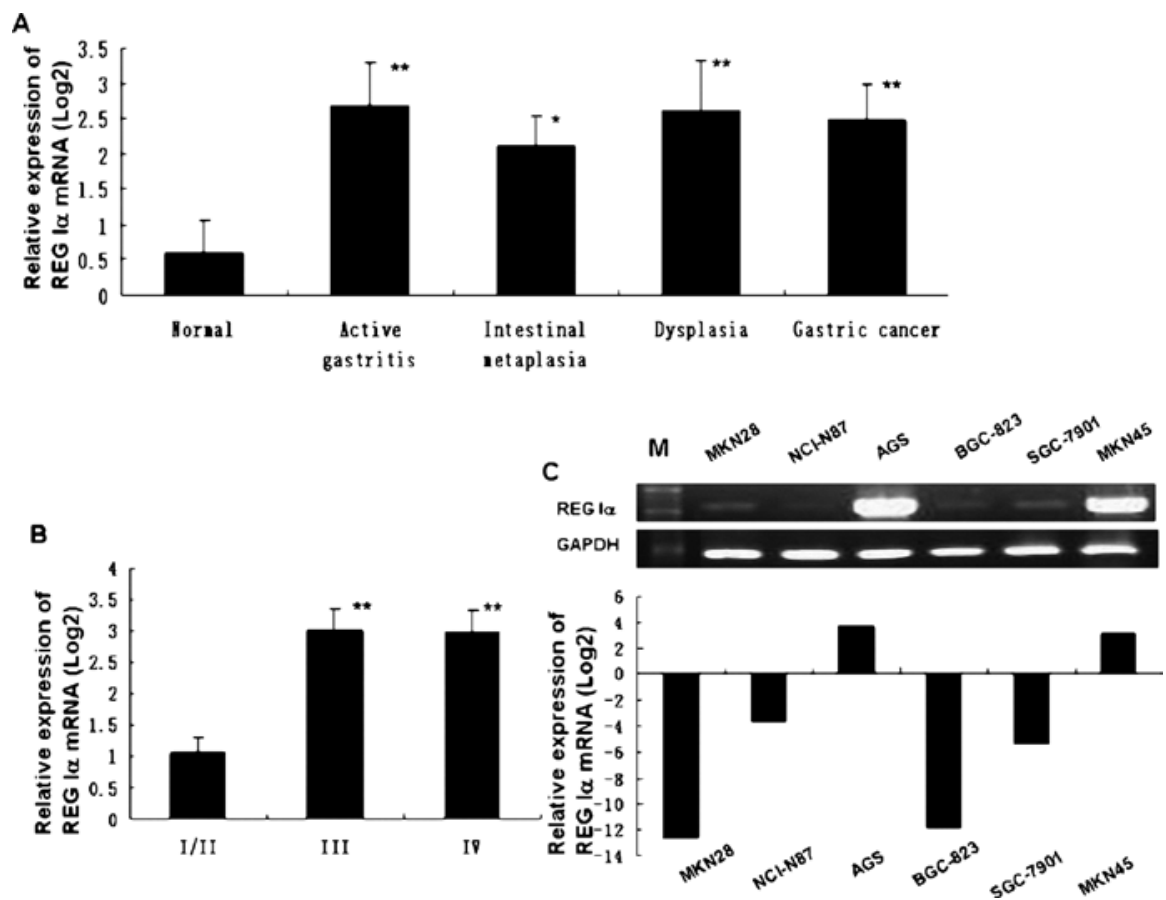

Figure 1. REG I $\alpha$ mRNA expression levels in gastric tissues and cell lines. (A) Q-PCR analysis of REG I $\alpha$ mRNA expression levels in gastric cancer tissue, precancerous lesions (dysplasia and intestinal metaplasia) and $H$. pylori-positive active gastritis relative to normal $H$. pylori-negative gastric tissue (Normal). (B) Relative levels of REG I $\alpha$ mRNA in gastric cancer of stage I/II or III/IV according to the TNM classification system. (C) The expression levels of REG I $\alpha$ mRNA in various gastric cancer cell lines, including MKN28, NCI-N87, AGS, BGC-823 SGC-7901 and MKN45, as determined by RT-PCR (upper panel) and Q-PCR (lower panel). Bars, \pm SE; ${ }^{*} \mathrm{P}<0.05,{ }^{* *} \mathrm{P}<0.01$.

Table II. Clinical characteristics of the enrolled patients.

\begin{tabular}{|c|c|c|c|c|c|c|c|c|c|}
\hline & \multirow[b]{2}{*}{ Normal } & \multirow{2}{*}{$\begin{array}{l}\text { Active } \\
\text { gastritis }\end{array}$} & \multirow{2}{*}{$\begin{array}{l}\text { Intestinal } \\
\text { metaplasia }\end{array}$} & \multirow[b]{2}{*}{ Dysplasia } & \multicolumn{4}{|c|}{ Gastric cancer } & \multirow[b]{2}{*}{ P-value } \\
\hline & & & & & Total & $\mathrm{I} / \mathrm{II}$ & III & IV & \\
\hline Number & 25 & 20 & 40 & 17 & 30 & 9 & 7 & 14 & \\
\hline Male/Female & $13 / 12$ & $11 / 9$ & $18 / 22$ & $11 / 6$ & $17 / 13$ & $5 / 4$ & $4 / 3$ & $8 / 6$ & $P>0.05$ \\
\hline Age (years) & $52.52 \pm 9.25$ & $52.15 \pm 7.94$ & $53.75 \pm 8.96$ & $57.00 \pm 9.96$ & $54.53 \pm 10.80$ & $54.44 \pm 13.09$ & $52.00 \pm 9.42$ & $57.79 \pm 9.63$ & $P>0.05$ \\
\hline H.pylori (-/+) & $25 / 0$ & $0 / 20$ & $24 / 16$ & $13 / 4$ & $18 / 12$ & $5 / 4$ & $5 / 2$ & $8 / 6$ & $\mathrm{P}<0.05$ \\
\hline Tumor size $(\mathrm{cm})$ & & & & & $5.59 \pm 2.63$ & $4.44 \pm 3.60$ & $5.91 \pm 1.68$ & $6.28 \pm 1.82$ & $\mathrm{P}<0.05$ \\
\hline \multicolumn{10}{|l|}{ Differentiation } \\
\hline High & & & & & 4 & 2 & 0 & 2 & $P>0.05$ \\
\hline Moderate & & & & & 6 & 2 & 2 & 2 & \\
\hline Low & & & & & 5 & 0 & 2 & 3 & \\
\hline Undifferentiated & & & & & 15 & 5 & 3 & 7 & \\
\hline
\end{tabular}

affects the expression of apoptotic signaling proteins during $\mathrm{H}_{2} \mathrm{O}_{2}$-induced apoptosis in MKN28 cells. Bad and caspase-3 expression was significantly decreased in MKN28 cells overexpressing REG I $\alpha$ relative to the negative control cells, whereas Bcl-xL expression was significantly increased, after induction of apoptosis with $200 \mu \mathrm{mol} / 1 \mathrm{H}_{2} \mathrm{O}_{2}$ for $6 \mathrm{~h}$ (Fig. 3D). The results of these experiments suggest that REG I $\alpha$ exhibits a critical anti-apoptotic activity in gastric cancer cells via the $\mathrm{Bad} / \mathrm{Bcl}-\mathrm{xL} / \mathrm{caspase}-3$ pathway.

Gastrin stimulates REG I $\alpha$ expression and induces $\beta$-catenin nuclear translocation in AGS cells. To determine whether gastrin stimulated REG I $\alpha$ expression, AGS cells were treated with increasing concentrations of gastrin-17 (G17), and cell proliferation was measured. The results of these experiments showed that G17 significantly promoted AGS cell proliferation in a dose-dependent manner (Fig. 4A). Q-PCR experiments showed that REG I $\alpha$ mRNA levels were elevated 4.18-fold following stimulation with G17 $\left(10^{-6} \mathrm{~mol} / \mathrm{l}\right)$ for $96 \mathrm{~h}$ (Fig. 4B). We also examined the total, cytoplasmic and nuclear $\beta$-catenin levels in AGS cells stimulated with G17 $\left(10^{-7}\right.$ or $\left.10^{-6} \mathrm{~mol} / \mathrm{l}\right)$ for 24 and $72 \mathrm{~h}$. Immunoblot analysis showed that the nuclear $\beta$-catenin levels were elevated, whereas cytoplasmic $\beta$-catenin levels decreased significantly in the G17-treated AGS cells $\left(10^{-6} \mathrm{~mol} / \mathrm{l}\right)$ at $72 \mathrm{~h}$. However, cytoplasmic and nuclear $\beta$-catenin levels were unchanged in the AGS cells treated with 

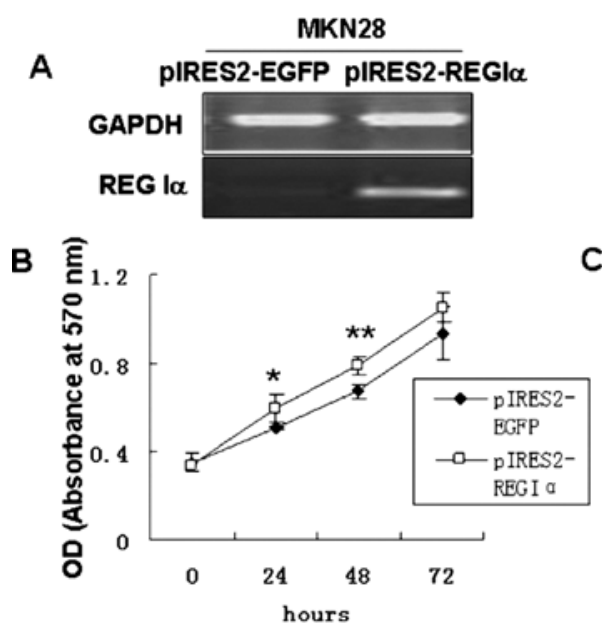

MKN45
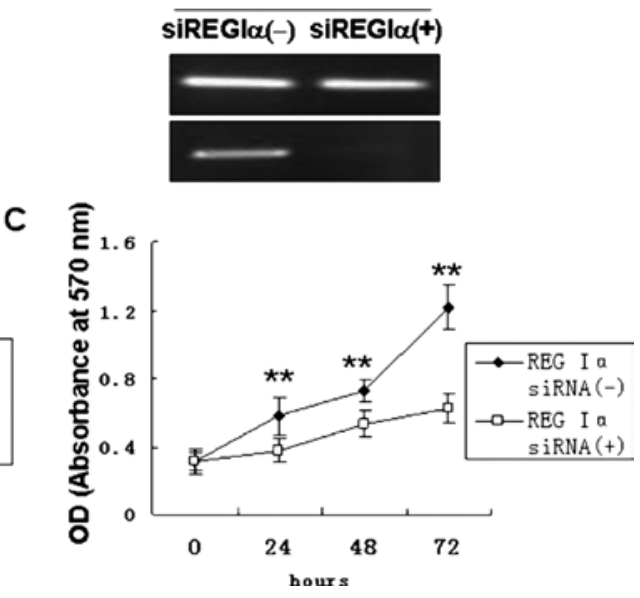

Figure 2. Analysis of REG I $\alpha$ function in gastric cancer cell proliferation. (A) Results of RT-PCR experiments for REG I $\alpha$ expression in MKN28 cells stably transfected with the pIRES2-REG I $\alpha$ expression vector or the pIRES2-EGFP negative control vector. (B) Results of MTT assays to analyze the cell growth of MKN28 cells stably transfected with the pIRES2-REG I $\alpha$ expression vector or the pIRES2-EGFP negative control vector at selected time points. (C) Results of MTT assays to analyze the growth of MKN45 cells stably transfected with the pCMV3.1-REG I $\alpha$ siRNA vector or a control siRNA vector at selected time points. OD (optical density, absorbance at $570 \mathrm{~nm}$ ) values represent the proliferative value, Bars, $\pm \mathrm{SE}$; ${ }^{*} \mathrm{P}<0.05,{ }^{* *} \mathrm{P}<0.01$.

A

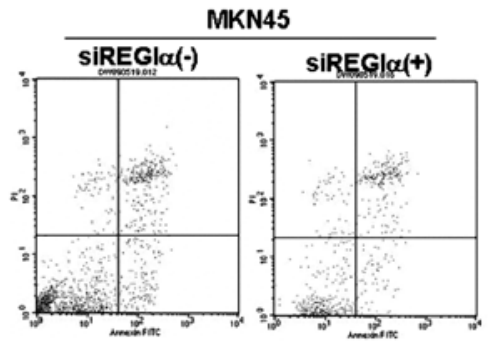

B

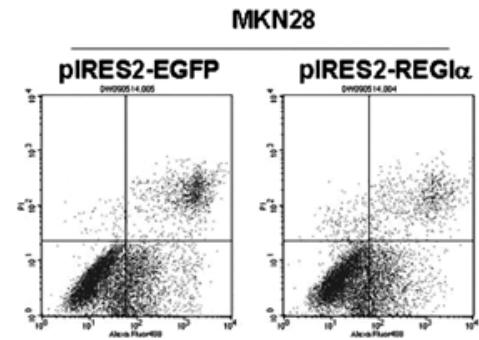

C

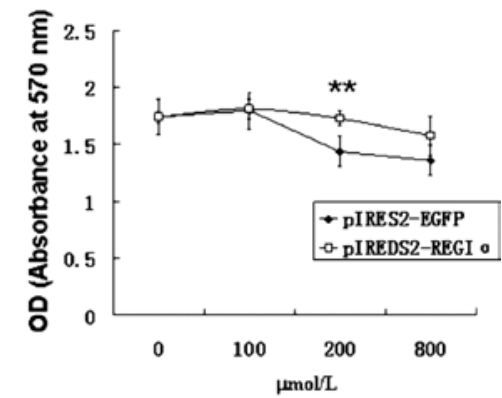

D

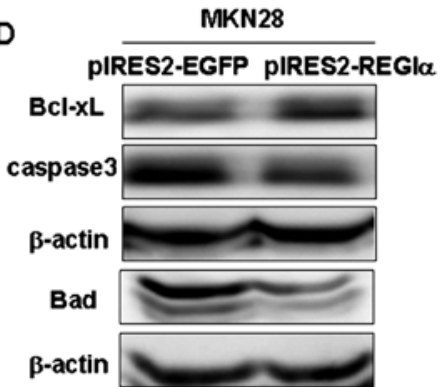

Figure 3. Anti-apoptotic activity of REG I $\alpha$ in gastric cancer cells associated with the Bad/Bcl-xL/caspase-3 pathway. (A) Annexin V-FITC flow cytometry to determine the percentage of apoptotic cells when MKN45 cells were stably transfected with either the pCMV3.1-REG I $\alpha$ siRNA vector (12.96 $\pm 0.5 \%)$ or the control siRNA vector (3.99 $\pm 0.3 \%$ ). (B) Annexin V-FITC flow cytometry to determine the percentage of apoptotic cells $(21.32 \pm 1.25$ and $27.14 \pm 0.82 \%$ for MKN28 cells transfected with either pIRES2-REG I $\alpha$ or pIRES2-EGFP). (C) MTT assays to analyze cell proliferation of MKN28 cells transfected with pIRES2-REGI $\alpha$ or pIRES2-EGFP. REG I $\alpha$-overexpressed MKN28 cell showed stronger cell activities than the empty vector transfected cells $(1.73 \pm 0.067$ vs. 1.44 $\pm 0.131, \mathrm{P}<0.01$ ). (D) Immunoblot analysis to determine $\mathrm{Bcl}-\mathrm{xL}$, Bad and caspase-3 expression of MKN28 cells stably transfected with either the pIRES2-REG I $\alpha$ vector or the control vector after treatment with $\mathrm{H}_{2} \mathrm{O}_{2}(200 \mu \mathrm{mol} / 1)$ for $6 \mathrm{~h}$. Bars, $\pm \mathrm{SE} ;{ }^{*} \mathrm{P}<0.05,{ }^{* *} \mathrm{P}<0.01$.

$10^{-7} \mathrm{~mol} / \mathrm{l} \mathrm{G17}$ (Fig. 4C). The results of these experiments suggest that gastrin may stimulate REG I $\alpha$ expression and induce $\beta$-catenin nuclear translocation in AGS cells.

\section{Discussion}

Recent studies have shown that inflammation plays a critical role in the development of cancer, including gastric cancer (4). REG I $\alpha$ protein is expressed at low levels in non-inflammatory gastric mucosa; in contrast, REG I $\alpha$ is markedly upregulated in inflammatory conditions and contributes to the maintenance of gastric tissue regeneration $(8,12)$. In the present study, REG I $\alpha$ expression was found to increase in patients with active $H$. pylori infection gastritis and in a rat model of active gastritis (data not shown).

Notably, studies have shown that REG I $\alpha$ has the ability to direct gastric cell differentiation towards parietal and chief cells in the neck zone, which is believed to house progenitor 

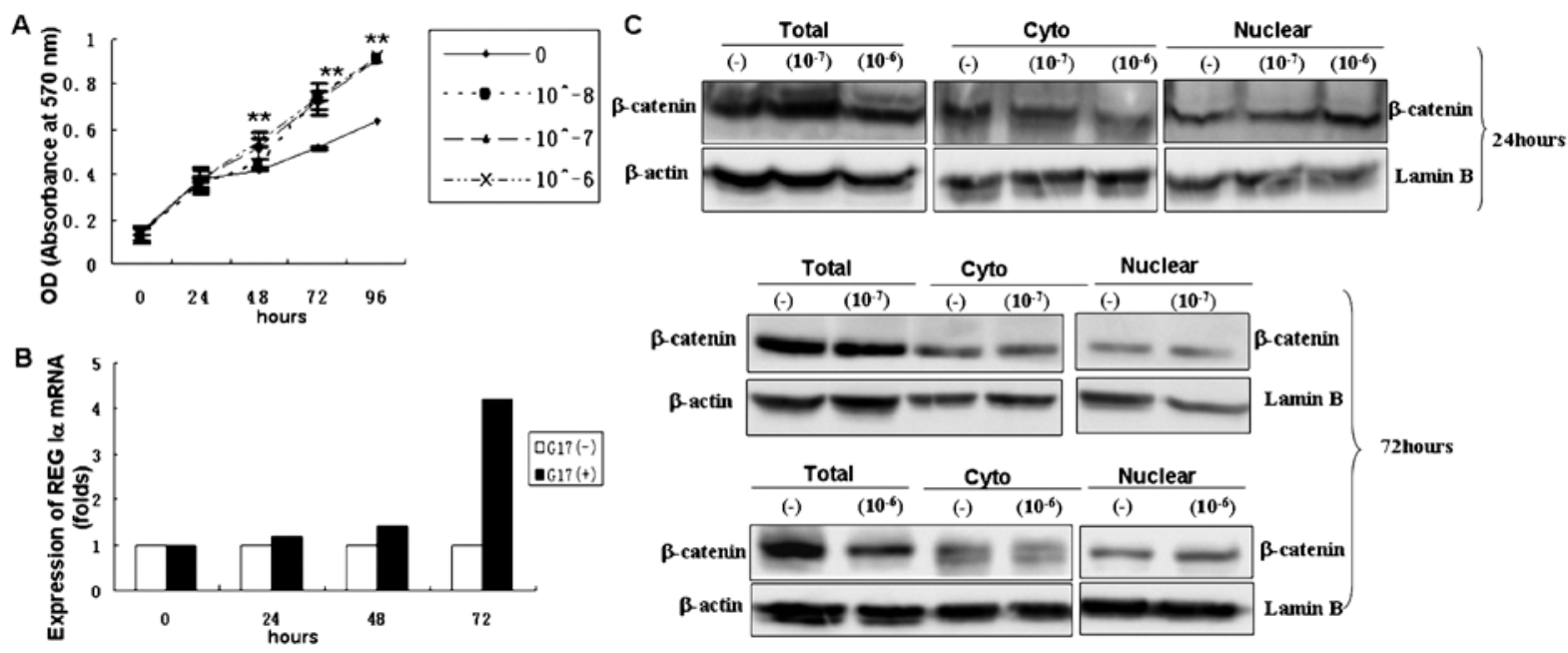

Figure 4. REG I $\alpha$ and $\beta$-catenin expression in AGS cells upon gastrin stimulation. (A) MTT assays to analyze the proliferation of AGS cells treated with different concentrations of gastrin (G17) $\left(0,10^{-8}, 10^{-7}\right.$ and $\left.10^{-6} \mathrm{~mol} / \mathrm{l}\right)$. (B) Q-PCR analysis of REG I $\alpha$ mRNA levels in AGS cells incubated with G17 (10-6 mol/1). (C) Immunoblot analysis of $\beta$-catenin expression in ABS cells treated with G17 $\left(0,10^{-7}\right.$ and $\left.10^{-6} \mathrm{~mol} / \mathrm{l}\right)$ for 24 and $72 \mathrm{~h}$. $\beta$-catenin expression was determined in whole-cell lysates (Total), cytoplasmic fractions (Cyto), and nuclear fractions (Nuclear) of AGS cells. ${ }^{*} \mathrm{P}<0.05,{ }^{* *} \mathrm{P}<0.01$.

cells of the gastric fundic mucosa $(13,14)$. In general, frequent stimulation of inflammation can lead to destruction and incomplete regeneration of the gastric gland, which predisposes cells to cancer. On the other hand, in vitro and in vivo studies have shown that inflammatory cytokines, such as CINC-2 $\beta$ and IL-6, may promote REG I $\alpha$ expression (22). REG I $\alpha$ may function as a growth factor in gastric gland tissue repair under inflammatory conditions. However, we cannot rule out the possibility that the growth effect of REG I $\alpha$ was exerted through an indirect mechanism involving the release of other growth factors, such as gastrin. Therefore, it is important to determine whether REG I $\alpha$ is involved in carcinogenesis associated with gastric inflammation, which may in turn lead to gastric premalignant lesions and eventually gastric cancer, as well as which factors may promote REG I $\alpha$ expression under these conditions.

A noteworthy finding of this study is that REG I $\alpha$ was frequently overexpressed not only in gastric cancer tissues, but also in intestinal metaplastic and atypical dysplasia, which are considered precancerous lesions $(3,5)$. Similarly, Harada et al (17) reported that REG I $\alpha$ protein was expressed in hyperplasias and low- or high-grade dysplasia in hepatolithiasis, suggesting that REG I $\alpha$ may play a role in the early stages of biliary carcinogenesis. A relatively small number of studies have suggested that REG I $\alpha$ is involved in pancreatic cancer and endocrine pancreas regeneration. In transgenic ElasCCK2 mice that express the gastrin receptor CCK2R, REG I $\alpha$ protein levels increased during the early steps of pancreatic carcinogenesis (23). Another REG family member, REG IV, was found to be upregulated in gastric IM, but was downregulated during malignant transformation of gastric epithelial cells (24). Unexpectedly, REG I $\alpha$ expression was unusually high in late TMN stage gastric cancer patients and poorly differentiated gastric cancer cells in the present study. We presumed that gastric cancer cells acquire the ability to produce the REG I $\alpha$ protein during the multistep carcinogenesis progression, resulting in a considerable growth advantage and the development of malignant phenotypes. The role of REG I $\alpha$ during the development from gastric premalignancy to gastric cancer should be addressed and clarified in future studies.

We found that REG I $\alpha$ overexpression enhanced, whereas REG I $\alpha$ downregulation inhibited, gastric cancer cell growth in in vitro experiments. Previous reports found that REG I $\alpha$ protein stimulated gastric epithelial cell proliferation in a dose-dependent manner $(19,25)$. In the present study, we also showed that REG I $\alpha$ mediates an anti-apoptotic effect on gastric cancer cells via the $\mathrm{Bad} / \mathrm{Bcl}-\mathrm{xL} / \mathrm{caspase}-3$ pathway. REG I $\alpha$ protein has been shown to rapidly induce tyrosine phosphorylation of cellular proteins and activate the extracellular-signal regulated kinase (ERK) 1/2 pathway, suggesting that REG I $\alpha$ may stimulate gastric cancer cell proliferation via the ERK1/2 pathway (26). Sekikawa et al (27) reported that REG I $\alpha$ protein promoted cell proliferation by enhancing Akt phosphorylation and Bcl-xL expression. Furthermore, a recent study suggested that REG I $\alpha$ protein mediates the antiapoptotic effect of STAT3 signaling via activation of the Akt/ Bad/Bcl-xL pathway by IL-6 stimulation (28). Taken together, it is clear that REG I $\alpha$ exhibits not only a growth-promoting effect, but also an anti-apoptotic effect on gastric cancer cells. Therefore, silencing the expression of REG I $\alpha$ through small RNA interfering techniques may provide a useful anticancer target therapy for gastric cancer and should be addressed in future studies.

In the present study, we confirmed that gastrin is an important regulator of REG I $\alpha$ in gastric cancer cell lines. However, the pathway for gastrin-mediated REG I $\alpha$ regulation has not yet been elucidated. We found that $\beta$-catenin accumulated and translocated to the nucleus when AGS cells were cultured with increasing concentration of gastrin. Therefore, we suggest that gastrin induces REG I $\alpha$ expression in gastric cancer cell via the $\beta$-catenin pathway. A recent study of liver cancer reported that REG I $\alpha$ and REG III $\alpha$ were possible downstream targets of the $\mathrm{Wnt} / \beta$-catenin 
pathway during liver tumorigenesis; $\beta$-catenin mutations induced REG I $\alpha$ and REG III $\alpha$ expression in liver cancer cells (21). $\beta$-catenin is a transcription cofactor with T-cell factor/lymphoid enhancer factor (TCF/LEF) in the Wnt pathway. Wnt stimulation leads to the inactivation of APC mutations or the activation of $\beta$-catenin mutations, resulting in nuclear accumulation of $\beta$-catenin, which subsequently complexes with TCF/LEF transcription factors to activate gene transcription (29). Activating mutations of the $\mathrm{Wnt} / \beta$ catenin pathway have been reported in gastric cancer and adenocarcinoma (30-32). Several individual TCF/LEF target genes have been identified, including c-MYC and cyclin D1, most of which have significant effects on cell proliferation, migration and metastasis. However, many questions remain regarding the possible pathways involved in REG I $\alpha$ regulation in response to gastrin stimulation.

In summary, increased REG I $\alpha$ expression was associated with late stages of gastric cancer and precancerous lesions. REG I $\alpha$ also promoted cell growth and exerted an anti-apoptotic effect on gastric cancer cells. Finally, gastrin stimulated REG I $\alpha$ expression via a potentially novel mechanism that may involve $\beta$-catenin phosphorylation and nuclear translocation. Taken together, these findings suggest a potential role for REG I $\alpha$ as a novel candidate biomarker for early diagnosis and prognosis of gastric cancer and as a possible therapeutic target.

\section{Acknowledgements}

This work was funded by the National '863' High-Tech Program (2006AA02Z470), Zhejiang Province Natural Science Program (Y206280) and Zhejiang Education Research Project (Y200702882), China. We appreciate Professor Xiaotong Hu of the Key Laboratory of Biotherapy of Zhejiang Province, Sir Run Run Shaw Hospital, Zhejiang University, School of Medicine, for the technical assistance and helpful discussion.

\section{References}

1. Kamangar F, Dores GM and Anderson WF: Patterns of cancer incidence, mortality, and prevalence across five continents: defining priorities to reduce cancer disparities in different geographic regions of the world. J Clin Oncol 24: 2137-2150, 2006.

2. Hartgrink HH, Jansen EP and van Grieken NC: Gastric cancer. Lancet 374: 477-490, 2009.

3. De Vries AC, van Grieken NC, Looman CW, Casparie MK, de Vries E, Meijer GA and Kuipers EJ: Gastric cancer risk in patients with premalignant gastric lesions: a nationwide cohort study in the Netherlands. Gastroenterology 134: 945-952, 2008.

4. Gonda TA, Tu S and Wang TC: Chronic inflammation, the tumor microenvironment and carcinogenesis. Cell Cycle 8: 2005-2013, 2009.

5. Fox JG and Wang TC: Inflammation, atrophy, and gastric cancer. J Clin Invest 117: 60-69, 2007.

6. Szabo S and Vincze A: Growth factors in ulcer healing: lessons from recent studies. J Physiol Paris 94: 77-81, 2000.

7. Tahara E: Growth factors and oncogenes in human gastrointestinal carcinomas. J Cancer Res Clin Oncol 116: 121-131, 1990.

8. Terazono K, Yamamoto H, Takasawa S, Shiga K, Yonemura Y, Tochino $\mathrm{Y}$ and Okamoto $\mathrm{H}$ : A novel gene activated in regenerating islets. J Biol Chem 263: 2111-2114, 1988.

9. Watanabe $\mathrm{T}$, Yonekura $\mathrm{H}$, Terazono $\mathrm{K}$, Yamamoto $\mathrm{H}$ and Okamoto H: Complete nucleotide sequence of human reg gene and its expression in normal and tumoral tissues. J Biol Chem 265: 7432-7439, 1990.
10. Fukui H, Franceschi F, Penland RL, et al: Effects of Helicobacter pylori infection on the link between regenerating gene expression and serum gastrin levels in Mongolian gerbils. Lab Invest 83: $1777-1786,2003$

11. Asahara M, Mushiake S, Shimada S, et al: Reg gene expression is increased in rat gastric enterochromaffin-like cells following water-immersion stress. Gastroenterology 111: 45-55, 1996.

12. Kawanami C, Fukui H, Kinoshita Y, et al: Regenerating gene expression in normal gastric mucosa and indomethacin-induced mucosal lesions of the rat. J Gastroenterol 32: 12-18, 1997.

13. Kinoshita Y, Ishihara S, Kadowaki Y, Fukui H and Chiba T: Reg protein is a unique growth factor of gastric mucosal cells. $\mathrm{J}$ Gastroenterol 39: 507-513, 2004.

14. Miyaoka Y, Kadowaki Y, Ishihara S, et al: Transgenic overexpression of Reg protein caused gastric cell proliferation and differentiation along parietal cell and chief cell lineages. Oncogene 23: 3572-3579, 2004.

15. Kimura N, Yonekura H, Okamoto $\mathrm{H}$ and Nagura $\mathrm{H}$ : Expression of human regenerating gene mRNA and its product in normal and neoplastic human pancreas. Cancer 70: 1857-1863, 1992.

16. Sekikawa A, Fukui H, Fujii S, et al: Possible role of REG Ialpha protein in ulcerative colitis and colitic cancer. Gut 54: 1437-1444, 2005.

17. Harada K, Zen Y, Kanemori Y, et al: Human REG I gene is up-regulated in intrahepatic cholangiocarcinoma and its precursor lesions. Hepatology 33: 1036-1042, 2001.

18. Tsutomu C, Hirokazu F and Yoshikazu K: Reg protein: a possible mediator of gastrin-induced mucosal cell growth. J Gastroenterol 35 (Suppl XII): 52-56, 2000.

19. Fukui H, Kinoshita Y, Maekawa T, et al: Regenerating gene protein may mediate gastric mucosal proliferation induced by hypergastrinemia in rats. Gastroenterology 115: 1483-1493, 1998.

20. Ono M, Sato H, Kazumori H, et al: Effect of a gastrin/CCK-B receptor antagonist, S-0509, on the omeprazole-induced proliferation of gastric mucosa in rats. J Lab Clin Med 142: 364-371, 2003.

21. Cavard C, Terris B, Grimber G, et al: Overexpression of regenerating islet-derived 1 alpha and 3 alpha genes in human primary liver tumors with beta-catenin mutations. Oncogene 25: 599-608, 2006.

22. Kazumori H, Ishihara S, Hoshino E, et al: Neutrophil chemoattractant $2 \beta$ regulates expression of the Reg gene in injured gastric mucosa in rats. Gastroenterology 119: 1610-1622, 2000.

23. Gigoux V, Clerc P, Sanchez D, et al: Reg genes are CCK2 receptor targets in ElasCCK2 mice pancreas. Regul Pept 146: 88-98, 2008.

24. Zheng HC, Xu XY, Yu M, Takahashi H, Masuda S and Takano Y: The role of Reg IV gene and its encoding product in gastric carcinogenesis. Hum Pathol 41: 59-69, 2010.

25. Kinoshita Y, Hassan S, Nakata H, et al: Establishment of primary epithelial cell culture from elutriated rat gastric mucosal cells. J Gastroenterol 30: 135-141, 1995.

26. Kadowaki Y, Ishihara S, Miyaoka Y, et al: Reg protein is overexpressed in gastric cancer cells, where it activates a signal transduction pathway that converges on ERK1/2 to stimulate growth. FEBS Lett 530: 59-64, 2002.

27. Sekikawa A, Fukui H, Fujii S, et al: REG Ialpha protein may function as a trophic and/or anti-apoptotic factor in the development of gastric cancer. Gastroenterology 128: 642-653, 2005.

28. Sekikawa A, Fukui H, Fujii S, et al: REG Ialpha protein mediates an anti-apoptotic effect of STAT3 signaling in gastric cancer cells. Carcinogenesis 29: 76-83, 2008.

29. Giles RH, van Es JH and Clevers H: Caught up in a Wnt storm: Wnt signaling in cancer. Biochim Biophys Acta 1653: 1-24, 2003.

30. Lee JH, Abraham SC, Kim HS, et al: Inverse relationship between APC gene mutation in gastric adenomas and development of adenocarcinoma. Am J Pathol 161: 611-618, 2002.

31. Woo DK, Kim HS, Lee HS, Kang YH, Yang HK and Kim WH: Altered expression and mutation of beta-catenin gene in gastric carcinomas and cell lines. Int J Cancer 95: 108-113, 2001.

32. Abraham SC, Nobukawa B, Giardiello FM, Hamilton SR and Wu TT: Sporadic fundic gland polyps: common gastric polyps arising through activating mutations in the beta-catenin gene. Am J Pathol 158: 1005-1010, 2001. 